\title{
A VIOLÊNCIA POLÍTICA DA ESCRAVIDÃO NO PENSAMENTO DE FRANCISCO JOSÉ DE JACA E GIORGIO AGAMBEN
}

\author{
THE POLITICAL VIOLENCE OF SLAVERY IN THE THOUGHT OF JOSÉ \\ FRANSCISCO JACA AND GIORGIO AGAMBEN
}

\author{
Antonio Justino de Arruda Neto \\ (netojustinoarruda@gmail.com)
}

\begin{abstract}
RESUMO
Este texto tem como objetivo a discussão entre o pensamento de Francisco José de Jaca O. F. M Cap. (1645-1690) e o Homo Sacer de Giorgio Agamben. Assim, a vida escrava na colônia espanhola amarga a condição de violência, a exceção e a supressão de direitos, argumentos esses convergentes dos pensamentos em discussão. Acrescido dessas acepções, Francisco José de Jaca, um frade que despontou como contrário à escravidão. Ele poderá ser considerado abolicionista? A afirmação é positiva. $\mathrm{O}$ propósito de Francisco José de Jaca em defender o indefensável no período colonial, resultou em sua convocação para Europa e aos tribunais eclesiásticos. De Sevilla à Roma. Seu instrumento de combate foi a simplicidade que estava ao seu alcance: a oração (pelo discurso) e a confissão (induzir o rebanho ao pensamento de liberdade). Sendo assim, o problema de pesquisa será: a escravidão política como um instrumento de violência seria o despojamento social e político da vida nua? Com isso, o objetivo geral é identificar a escravidão política como um instrumento de violência como procedimento de despojamento social e político da vida nua. O texto está dividido em três seções articuladas? nos pensamentos de Francisco José de Jaca e Giorgio Agamben: a primeira, compreender o pensamento de Francisco José de Jaca, segunda, discutir a invisibilidade da escravidão; e, a terceira, a análise da retirada da escravidão humana do mundo, é possível? Portanto, os herdeiros indiretos de Francisco José de Jaca, no Brasil, foram muitos, entre eles, Joaquim Nabuco (1849-1910).
\end{abstract}

Palavras-chave: Escravidão. Homo Sacer. Liberdade. Francisco José de Jaca. Giorgio Agamben.

\section{ABSTRACT}

This text has as objective the discussion between the thought of Francisco José de Jaca O. F. M Cap. (1645-1690) and the Homo Sacer of Giorgio Agamben. Thus, slave life in the Spanish colony bitter the condition of violence, the exception and the suppression of rights, arguments that converge from the thoughts under discussion. Added to these meanings, Francisco José de Jaca, a friar who emerged as opposed to slavery. Can he be considered abolitionist? The statement is positive. Francisco José de Jaca's purpose in defending the indefensible in the colonial period resulted in his being summoned to Europe and the ecclesiastical courts. From Seville to Rome. His combat instrument was the simplicity that was

\footnotetext{
${ }^{1}$ Mestrando em Filosofia pela Universidade do Vale do Rio dos Sinos (UNISINOS). CV Lattes: http://lattes.cnpq.br/7347743859850934.

ORCID: https://orcid.org/0000-0001-5188-3198.
} 
within his reach: prayer (by speech) and confession (inducing the flock to the thought of freedom). Thus, the research problem will be: is political slavery as an instrument of violence the social and political spoilage of naked life? Thus, the general objective is to identify political slavery as an instrument of violence as a procedure of social and political dispossession of naked life. Is the text divided into three articulated sections? in the thoughts of Francisco José de Jaca and Giorgio Agamben: the first, to understand the thoughts of Francisco José de Jaca, second, to discuss the invisibility of slavery; and the third is the analysis of the withdrawal of human slavery from the world, is it possible? Therefore, the indirect heirs of Francisco José de Jaca, in Brazil, were many, Joaquim Nabuco (1849-1910).

Keywords: Slavery. Homo Sacer. Freedom. Francisco José de Jaca. Giorgio Agamben.

\section{INTRODUÇÃO}

Gostaríamos de abordar a correspondência da escravidão com o Homo Sacer advindo do direito romano. O elemento comum é o processo político de negação do outro. Visto que o tempo da escravidão foi inerente a determinado período da história, nesse caso o colonialismo europeu nas Américas. Francisco José de Jaca (O. F. M Cap.) foi enviado para realizar sua missa no caribe, e assim esse frade menor realiza a travessia da fé para o debate político no Novo Mundo. No que se refere a figura do Homo Sacer é referência ao indivíduo retirado de sua condição de vida social e política em comunidade. Destarte, o ano de 1681 em 28 de agosto. Esse para Francisco José de Jaca (1645-1690), o começo da missão, pois seu escrito Resolución Sobre la Libertad de los Negros y sus Originarios, en Estado de Paganos y Después ya Cristianos (1645), sobre a liberdade estava concluído. A 'oração e a confissão' foram traduzidas em ação, o enviar para leitura real do sentimento de liberdade individual. Esse não era tema conveniente para o momento de produção econômica das colônias e lucros da Metrópole.

Por conseguinte, das palavras iniciais introdutórias à influência teórica, é o pensamento de Tomás de Aquino, para Francisco José de Jaca, no começo da formação dos estudos na ordem Capuchinha. Entretanto, o autor em discussão é Francisco José de Jaca, frade conhecido como contrário à escravidão. Pois, a consequência em defender o indefensável, o escravo, foi a sua convocação para a Europa e aos tribunais eclesiásticos. De Sevilla à Roma, 'todos os caminhos o levavam para Havana', seu ambiente de atuação.

Seu instrumento de luta, a fala (o discurso), como meio de combate que estava ao seu alcance: primeiro, a oração (ação) e a confissão (induzir o rebanho ao pensamento de liberdade). Sendo assim, o problema de pesquisa que orienta este estudo é: a escravidão política como um instrumento de violência seria o procedimento de despojamento social e político da vida nua? Dessa maneira, o objetivo geral será identificar a escravidão política como um instrumento de violência seria o procedimento de despojamento social e político 
da vida nua. O texto está dividido em três seções articuladas nos pensamentos de Francisco José de Jaca e Giorgio Agamben: a primeira, compreender o pensamento de Francisco José de Jaca e a segunda, discutir a invisibilidade da escravidão; e, a terceira, a análise da retirada escravidão humana do mundo, é possível? Portanto, os herdeiros indiretos de Francisco José de Jaca no Brasil, foram muitos, Joaquim Nabuco (1849-1910) o mais conhecido nacionalmente, contudo, a semente da abolição procrastinou em germinar nas terras brasileiras.

O Homo Sacer, discutido por Giorgio Agamben em sua coleção sobre o tema não representa um impedimento de conteúdo para essa discussão. Pois, o escravo para o comércio colonial era uma 'coisa', não exprimia vida própria ou tinha vontade, simbolizava a profanação da dignidade daquilo que é humano. O Homo Sacer, retirado e desprovido de direito, havia

perdido também o direito ao nome. À vista disso, a convergência de pensamento entre Giorgio Agamben com seus escritos do projeto Homo sacer: Homo Sacer: O Poder Soberano e a Vida Nua I(1995) e Francisco José de Jaca com seu principal escrito: Resolución Sobre la Libertad de los Negros y sus Originarios, en Estado de Paganos y Después ya Cristianos (1645), estar na negação do espaço público pelo poder político e à convivência comunitária, tanto para o escravo, quanto para o homem sacro.

\section{COMPREENDER O PENSAMENTO DE JOSÉ JACA}

Ante de discorrer sobre o pensamento de Francisco José de Jaca, importante destacar a influência que recebeu de Tomás de Aquino. Na Suma Teológica (2001)), destina uma questão ao Direito, além de apontar outro questionamento sobre a escravidão e sua conexão com o pensamento aristotélico: o direito como um objeto de justiça, contudo, os atos da escravidão são justos? Ou haverá povos que devem ser escravizados pela sua condição de inferioridade intelectual ou econômica? Sendo assim, Francisco José de Jaca enfatiza: “É lícito capturar com violência e enganar os negros, assim como os outros nativos feitos injustamente escravos?" (Jaca, 2002, p. 35). As respostas para esses questionamentos serão apreciadas no âmbito teológico e pelo direito de Estado ou Canônico.

Ao enfrentar o discurso majoritário em defesa ao sistema da escravidão como uma ideologia de mercado e Estado, Francisco José de Jaca assumiu o compromisso de vida, ou seja, de reestabelecer a sua formação clerical e confirmar a sua prática cristã? Havana é o local de suas primeiras pregações, conforme relata sua biografia. Suas pregações indicavam um traço positivo, ou seja, de combater a lei de Estado com o debate e 
sua ilicitude (JACA, 2002). O debate dava-se no sentido da sagrada escritura com os decretos institucionais (a vontade dos homens).

Outro questionamento, realizado pelo autor foi a questão de justiça, ou seja, seria justo manter uma pessoa na condição de escravo, mesmo depois de seu batismo? Com isso, o batismo, que é o símbolo da confirmação, de ser denominado pelo nome, de ser participante da comunidade, ter acesso ao ambiente público - o contrário, pagão é o renegado da sociedade. O batismo, em referência ao pensamento de Giorgio Agamben e José de Jaca, representa a metáfora 'o retirar da escuridão' o ente perdido, retomar o nome de origem e ter acesso ao convívio social. Esse é o elemento de confirmação da fé e com a volta a comunidade política. Logo, o sentido contrário é negar um dos principais sacramentos da Igreja Católica. Para ser argumento de confirmação da salvação do indivíduo, contudo, o batismo foi utilizado para confirmação de negócios, para afastar o pecado de quem adquiria algum escravo, pois, nesse sentido o senhor daria a 'condição de gente', aquele capturado e vendido como um objeto. Esse era o argumento utilizado pelos defensores do sistema de trabalho escravo colonial, ou seja, uma apropriação do discurso teologal para justificação da escravidão.

No artigo terceiro, da questão 57 sobre o direito, Aquino apresenta a seguinte acepção: "Demais - A escravidão é natural entre os homens; pois, como diz o Filósofo, alguns são naturalmente escravos. Ora, a escravidão é própria do direito das gentes, segundo Isidoro. Logo, o direito das gentes é o direito natural” (AQUINO,2001 p. 2097). Destaquemos as seguintes passagens: a primeira 'naturalmente' e a segunda é a 'própria do direito das gentes'. Sendo que a resposta, segundo Aquino, seria

RESPOSTA À SEGUNDA. - A razão natural não dita, absolutamente falando, que seja escravo, antes o indivíduo tal, que tal outro. Mas, isso só pode ser por alguma utilidade consequente, pela qual seja útil a um ser governado por outro, mais sábio, e seja útil a este ser ajudado por aquele, como diz Aristóteles. Por onde, a escravidão, pertencente ao direito das gentes, é natural, do segundo modo, mas não, do primeiro (2001, p. 2098).

Quanto à resposta do pensamento aristotélico na obra de Aquino, lembra-nos no sentido de indicar a condição e capacidade de alguns povos autogerirem ou recusa de possuírem intelecto, esses poderiam ser escravizados pela incapacidade social, intelectual e política. sobre a Metafísica, Aristóteles (2002), preconiza inicialmente que todos os indivíduos sociais pretendem o conhecimento para conviver em comunidade, isso em sociedade considerada não-bárbara. Aquela que comungava com a cultura grega. Sendo assim, Aquino (2001) exterioriza o seu pensamento contrário à escravidão como uma não- 
condição natural entre os homens e sociedades. Contudo, para a premissa aristotélica, apresenta-nos uma confirmação em relação ao conhecimento como paradigma racional da comunidade e aos membros, que deveria evitar o escravizar do outro, neste entendimento

O problema da escravidão no século dezessete é sem dúvida uma aporia que a filosofia e teologia escolástica colonial latina tiveram de enfrentar, isto se deu com uma diversidade ampla de posições teóricas que nem sempre foram convergentes, em termos de comércio e suas várias implicações (DECOTHÉ JÚNIOR, 2017, p.21).

As implicações do direito ao Estado colonial em ser parte contratual, seriam o elemento legitimador invocado pelas Instituições reais. Dessa maneira, características coercitivas exprimem duas acepções: a primeira em legitimar à vontade em escravizar, e a segunda como confirmação da condição humana em 'coisa'. Por esse motivo, o questionamento: Quando o homem passa a ser considerado objeto (coisa)? Respondemos essa indagação, com o termo 'coerção', ou seja, o direito em impor algo para o outro. Ou ainda, o impedir a convivência social e negar a condição de ser humano, esse seria o processo de coisificação do homem, isto é, a ausência de dignidade. Assim, o direito real colonial, por meio das concessões aos comerciantes, regulamentou o processo de desumanização do outro. Por isso, a colônia poderia ser denominada como 'campo', o lugar do não-humano.

Não obstante, uma voz ecoou nas colônias do Atlântico. O pensamento de Jaca não estaria em pensar a legitimação do direito em ter escravo ou de escravizar o outro. Diante disso, após a captura do humano e tutelada por meio do direito estatal, o capturado passa a não ter nome, lar, ou seja, o paradoxo da morte civil para o nascer como um bem material. $\mathrm{O}$ capuchinho em suas reflexões, apresenta sua opinião contrária aos argumentos legitimadores do processo comercial da escravidão negra. Em razão disso, quis debater a não escravidão dos milhares que chegavam dos portos da África. Sendo assim, Decothé Júnior, indica

\footnotetext{
Os autores que tratam do tema da escravidão colonial negra à época, estão preocupados em justificar por meio de títulos este sistema de subserviência, porém, como consequência disto, o que eles tratam é de apenas apaziguar as consciências dos escravocratas por meio da discussão da legitimidade ou não destes títulos de escravidão. Contudo, e, ao contrário desta postura, temos a inovadora dialética crítica que além de ter sido encetada por Francisco José de Jaca, também teve força na ação abnegada do frade Epifanio de Moirans OFMCap (1644-1689) em suas práticas e escritos (2017, p. 22).
}

A questão da legitimidade foi ponto de divergências políticas e sociais nas colônias. Um exemplo, foi o debate de Sepúlveda e Las Casas sobre a questão da 
escravidão indígena. A opinião por catequizar e batizar foi vencedora, Las Casas convenceu o Real Conselho em Valladolid. Para que as insurgências não ocorressem para a manutenção da ordem política e comercial nas colônias, Carlos II, monarca espanhol, iniciou uma série de reformas administrativas como forma de apaziguar as disputas da época. Contudo, o problema não estava apenas na legitimação em aceitar, apresentava-se no pensamento contrário sobre a legitimação da escravidão. Nesse sentido

O pensamento antiescravagista de Francisco José de Jaca é uma inovadora e fundante manifestação crítica de oposição da instituição da escravidão que era praticada contra os povos negros africanos. O frade capuchinho unido ao seu irmão de ordem se constitui como um dos primeiros pensadores da época que faz uma crítica ferrenha a ideologia da escravidão, e propõe a libertação destas pessoas que são vítimas da escravidão institucionalizada em pleno século de ouro espanhol (DECOTHÉ JÚNIOR, 2017, p.22).

Na passagem anterior, importante destacarmos que não se trata uma vontade subjetiva dos comerciantes em possuir escravos. Encontrava-se fundamento na ideologia, ou seja, no compartilhamento ideário escravocrata por uma sociedade colonial e para a Metrópole. A condição de ser escravo, sendo legitimada pelo direito real (o positivo), seria a circunstância de rompimento com a questão do direito das gentes sustentada por Aquino (2001). O batismo cedido aos índios era válido, mas não tinha o mesmo significado para os africanos. Para o cristão católico, importante, destacar a máxima da criação em ser a semelhança do seu criador e não uma exceção ou suspensão sobre constituir a filiação católica, consequentemente, com o Estado. Para os defensores da escravidão, o comércio era condição de afinidade pela prática em questão. Contudo, não ocorreu a primeira premissa do entendimento cristão, o 'Amai-vos como irmãos', para Jaca, a questão estava em defender a máxima do pensamento cristão, 'filhos do mesmo pai’. Nessa lógica

[...] pois a sua atenção está posta na noção de direito humanos e na ação moral de católicos que sejam pessoas éticas, no sentido de encararem todos os seres humanos como iguais em sua condição de criatura e isto sem nenhuma distinção de raça. A fundamentação de Jaca neste quesito é a ideia de que todas as pessoas foram formadas a imagem a semelhança do próprio Deus (DECOTHÉ JÚNIOR, 2017, p.32).

Sendo assim, o argumento principal do autor, sobre a semelhança com o criador e a humanidade em si, sendo assim a sociedade colonial utilizou meios para não retirar a escravidão do período mercantilista e expansionista. Lembrar que o argumento da escravidão, em uma digressão temporal, indicou uma escravidão por dívidas até por 
conquistas (guerra justa). Outro aspecto da justificação, esse contraditório, razão do nome que o escravo recebeu no período colonial, 'amigo do senhor' (caso tivesse a condição do diálogo). Portanto, os argumentos retóricos para legitimar a escravidão, foram denominar o humano em 'servo', essa categoria é intrínseca sobre a condição de liberdade e evitar a negação da humanidade ao indivíduo.

\section{A ESCRAVIDÃO E O HOMO SACER}

O conceito abordado por Agamben (2002) em seu projeto Homo Sacer, retrata a questão do homem sacro, como aquele que é desprovido de direitos, que vive em uma zona de anomia. A escravidão negra representa o Homo Sacer do período colonial, ou seja, do sistema mercantilista. A característica comum do indivíduo romano em Giorgio Agamben e do indivíduo africano em Francisco José de Jaca seria o conceito de retirada, primeiro seria a questão política e o segundo o social em razão do convívio em comunidade. O homo sacro teria o direito de reabilitação, com isso, uma reposição de bens e do nome. O escravo não teria esse direito, apenas em casos extremos o direito de liberdade, embora o social e os bens não sejam passíveis de reparação. Por exemplo, salvar o Senhor de escravos de alguma situação de ameaça ou agressão.

A exceção estaria no ato do soberano, nesse caso o senhor de escravo, ao exercer todo poder em seu domínio, seria a voz das leis reais. A exceção tornou-se um instrumento para a imposição do poder político, social e econômico durante o processo da escravidão colonial. $\mathrm{O}$ modo como este instrumento confirma os meios políticos é pelo apagamento social, político e econômico, ou seja, de uma forma-de-vida, com isso uma vida de hábito subordinado ao trabalho. Por isso, a questão de convergência entre o pensamento de Francisco José de Jaca e Giorgio Agamben é a questão da retirada política do indivíduo e o processo de violência como instrumento de desumanizar o outro, isso para Agamben seria o 'campo', para Francisco José de Jaca a questão de não confirmar o batismo, primeiro como meio cristão, segundo como instrumento jurídico-político a questão do direito de ter um nome.

Após esses aspectos introdutórios, seguiremos na discussão do pensamento de Giorgio Agamben, primeiro sobre o Homo Sacer, por conseguinte, o campo. Sabemos que o 'campo' em questão está no contexto da retirada do indivíduo de seu espaço público, negando-lhe a liberdade e a sua vida política. Essa ação desenvolvida pelo agente político e por indivíduos comuns da comunidade, legitimado pelas leis, 
denominamos de poder do soberano, ou seja, seus atos de poder são práxis para exceção. Sendo assim, o escravo, como Homo Sacer, enfrenta o paradigma do campo como local de perda de identidade política, social e com base na extrema negação de sua existência, a sua condição de ser humano. Nesse contexto, a discussão sobre o Homo sacer é

Mais do que resolver a especificidade do homo sacer, como se tem feito muito frequentemente, em uma pretensa ambiguidade originária do sagrado, calcada sobre a noção etnológica de tabu, tentaremos em vez disso interpretar a sacratio como uma figura autônoma e nos preguntaremos se ela não nos permitiria por acaso lançar luz sobre uma estrutura política originária, que tem seu lugar em uma zona que precede a distinção entre o sacro e o profano, entre religiosos e jurídico (AGAMBEN, 2002, p. 81).

A preocupação de Agamben sobre o que seria o Homo Sacer, para o período romano, seria o paradoxo da vida, ou seja, uma vida sacra (estava na tutela dos deuses). Para o convívio terreno, era uma vida desprezada pelo direito e pela política. Contudo, não era uma vida totalmente posposta ao desprezo social, político e do direito, poderia esta ser resgatada pela vontade política do soberano e pelo pedido da comunidade à qual o indivíduo era parte. Quanto ao escravo do período mercantilista, quem poderia questionar sua condição política? Era possível um resgate para a sua comunidade de origem? Os motivos para a escravidão no continente africano, em especial nos países da costa, eram por meio da guerra, consequentemente, captura dos derrotados e vendidos para os comerciantes.

Sendo assim, a sua comunidade de origem não teria a condição do resgate social, político e jurídico. Entretanto, a liberdade poderia ser concedida àquele que era denominado de escravo, com isso ganhava um nome e deveria seguir os preceitos jurídicos da comunidade secundária, isso representa a ambivalência da condição de vida.

O Homo Sacer é fruto do abandono da política de reconhecimento do outro como partícipe do espaço público. O escravo é fruto dessa fragmentação do conceito de vida em negar o outro. Por isso, o processo político na colônia era a negação completa pelo senhor-de-escravo perante à condição de liberdade e de vida, isto é, seus atos não tinham controle externo, pois eram representantes da política real, eram bons pagadores de impostos para a coroa, isto bastava para um processo salutar entre a política de mercado e o Estado. Sendo que esse processo de desumanização está contido na instrumentalização política e a transformação do humano em um Homo Sacer (SANTOS, 2014). Decerto, o primeiro elemento da exceção é 'capturar' o outro, por meio da violência, sendo assim 
A exceção é uma espécie da exclusão. Ela é um caso singular, que é excluído da norma geral. Mas o que caracteriza propriamente a exceção é que aquilo que é excluído não está, por causa disto, absolutamente fora de relação com a norma; ao contrário, esta [sic] se mantém em relação com aquela na forma da suspensão. A norma se aplica à exceção desaplicando-se, retirando-se desta. O estado de exceção não é, portanto, o caos que precede a ordem, mas a situação que resulta da sua suspensão. Neste sentido, a exceção é verdadeiramente, segundo o étimo, capturada fora (ex-capere) e não simplesmente excluída (AGAMBEN, 2002, p. 25).

Os argumentos políticos, sociais ou econômicos foram utilizados para legitimar a escravidão, como um processo necessário para as colônias: "O controle biopolítico que o estado de exceção exerce sobre o indivíduo o descaracteriza de sua identidade de cidadania e jurídica" (SILVA, 2016, p. 167). Referindo-se a soberania exercida sobre a vida do escravo representava uma única finalidade, controlar a vida do escravo para o bem da produção econômica. O local específico foi as senzalas, o 'campo', local da não humanidade, o homem foi transformado em propriedade (coisa), não apresentando dignidade. Por isso

Ora, se a morte nos campos do século vinte é um epifenômeno, algo que vem em acréscimo sem alterar a configuração da coisa, se ela é acessória, se é um reflexo secundário, então a mencionada diferença se reduz ainda mais, uma vez que nas senzalas a morte era em princípio o resultado da exploração e do esgotamento físico e mental, um último infortúnio para o escravo e um fim não desejado pelo senhor (NASCIMENTO, 2016, p. 25).

A preocupação de José Jaca, como franciscano, era defender a liberdade como princípio e direito, por isso evitar a escravidão como violência. O não compreender da sociedade colonial em defender a escravidão como procedimento social e econômico fez com que José Jaca compreendesse o sentido de lutar pela liberdade. Por conseguinte, ocorreu seu questionamento em ser contrário à prática escravocrata, pois, o homem foi transformado em objeto (coisa) e tendo sua humanidade retirada para ser vendido. Isso deveria ser combatido, pois o homem era reflexo da vontade divina e precisaria ser tratado como herdeiro desta vontade em sua comunidade e ser equiparável no contexto de sua vida.

Portanto, a falta de compreensão dos defensores em não escravizar o outro, foi a luta de Francisco José de Jaca contra o sistema político e social, vigente de sua época. A sua compreensão estava interligada com a questão da empatia em um direito comum, ou seja, o nascer livre perante Deus. $\mathrm{O}$ fato de nascer com as características biológicas distintas não são argumentos para suprimir a liberdade do outro. Realizando um comparativo de 
pensamento, hoje, teríamos uma aproximação com o Homo Sacer, discutido por Giorgio Agamben (2002).

Dessarte, o homem, sem direitos, esquecido por seu nome. Sendo a escravidão e a invisibilidade, seria no sentido de negar a condição de ser sociável em seu local de origem, para se tornar um corpo oco, movido não por sua vontade e sim pela vontade do seu Senhor, isso é uma "Forma-de-vida assume a função de paradigma ideal para o conceito de vida, em contraponto à divisão de qualificações promovidas pelas formas de vida" (BAPTISTA, 2014, p. 61). Ao Homo Sacer, esse teria a oportunidade em retomar sua condição inicial e ser reconhecido pelo nome e por seu direito de ser livre. Ao escravo essa condição foi atrasada pela não vontade do outro em acolhê-lo como igual e em prolongar a política de escravidão nas colônias

A questão da invisibilidade da escravidão é o não entendimento das premissas cristãs, pois, a sociedade colonial e a metrópole, intercalavam a vontade do não compreender em realizar comércio, pois, o lucro era o mais importante. A justificação da escravidão era uma necessidade objetiva, ou ainda, uma permuta de favores entre a Instituição Estado, na figura do Rei e da classe dos investidores/mercadores, sendo assim, o discurso contrário a escravidão seria o possível eco da 'ruína' do poder real nas colônias. Portanto, o colapso do reino é inerente a violência desempenhada pelos seus representantes, por meio da instituição do campo, como dito anteriormente, a senzala representa este elemento, por isso

O campo é somente o lugar no qual se realizou a mais absoluta condicio inhumana que já se deu sobre a terra: isso é, em última análise, aquilo que conta, para as vítimas e para seus pósteros. Seguiremos, aqui, deliberadamente uma orientação contrária. Em vez de deduzir a definição do campo dos eventos que se deram ali, iremos nos perguntar antes: o que é um campo, qual é sua estrutura jurídico-política, por que acontecimentos semelhantes puderam ter tido lugar ali? Isso nos levará a olhar para o campo não como um fato histórico e uma anomalia pertencente ao passado (mesmo que, eventualmente, ainda verificável), mas, de algum modo, como matriz oculta, o nomos do espaço político no qual ainda vivemos (AGAMBEN, 2017, p. 41).

A 'senzala' como símbolo do 'campo', representa o conjunto de instrumentos pertencentes à violência, consequência da escravidão. ${ }^{2}$ Após o fim da escravidão negra, os locais de prisão são a vergonha dos herdeiros das fazendas, discutir representa uma dificuldade, ocultar o espaço físico é a facilidade encontrada por estes. A 'senzala' é o encontrar

\footnotetext{
${ }^{2}$ Tese defendida pelo Professor Castor M. M. Bartolomé Ruiz em interação com o pensamento de Giorgio Agamben.
} 
do humano com o desumano, poderíamos considerar que é a técnica da exceção ou da retirada total do indivíduo da comunidade social e política. Outra consequência do ambiente da exceção seria a benevolência dos escravos que ganhavam roupas para serem cortesãos ou acompanhantes, ou seja, os que moravam na 'casa-grande', esses habitavam e conviviam com a falsa condição política de liberdade. Com isso, mesmo com a mudança de local, a exceção continuava, essa benevolência do Senhor era mais um instrumento de dominação. Sendo assim

\begin{abstract}
A exceção e o campo foram idealizados como técnicas biopolíticas que permitem obter um controle quase absoluto das vidas humanas consideradas perigosas. Esta condição instrumental da exceção e do campo torna sua realidade uma sombra sempre potencial. Elas são técnicas de governo, cuja característica principal é desencadear uma forma de violência estrutural que coloca avida humana sob o arbítrio de uma vontade soberana. O campo e a exceção são técnicas biopolíticas de controle social (RUIZ, 2014, p. 55-56)
\end{abstract}

Diante disso, os argumentos em relação ao ‘campo', referentes às técnicas de governo empregadas inicialmente pelos comerciantes de escravos, no passado, ou seja, atos de negar o a condição de humano. Estes foram replicados no século passado e continuam a serem, mecanismos de exceção. Por isso, Francisco José de Jaca defende o fim da escravidão com argumentos teológicos e políticos, pois podemos considerá-lo, combatente ao sistema governamental referente ao sistema escravista. Pois, sua primeira premissa está no fato de que o homem é a semelhança de deus, conforme narrativa do livro da criação (gênese).

Outro argumento, seria o 'direito das gentes'. Esse seria o ponto de convergência para que sociedades distintas convivessem em harmonia, ou seja, a questão do aceitar o outro em comunidade e nas relações sociais. Além disto, explicar a questão da compra do humano por outro seria o argumento retórico contido no princípio da boa-fé, este, desde o direito romano, ensejaria a responsabilidade da licitude ou não de um negócio. Francisco José de Jaca (2002) argumenta que a posse da liberdade é pertencente à pessoa, por meio do seu nascimento e condição de gente, conforme, a confirmação da fé pelo batismo cristão católico. Por isso, mesmo com a boa-fé do adquirente, o negócio da escravidão seria ilícito, por isso:

La libertad es algo constitutivo del ser humano y que no puede ser olvidada por cualquier pecado. Entiende que peca tanto el comprador como el vendedor, de tal manera que los compradores sean conscientes que también ellos son cupables; puesto que si ellos no compran esclavos, se puede terminar com el negocio fraudulento y pecaminos. (JACA, 2002, p. 73). 
A Confirmação do autor em destacar a questão da liberdade como inerente ao ser humano é a premissa maior de sua defesa, pois negociar a liberdade não é constitutivo de uma sociedade salutar. Todavia, a própria sociedade não compreendeu o sentido de liberdade humana, com isso não ocorreu a empatia pelo direito das gentes. $\mathrm{O}$ homem não poderia ser reduzido a um objeto, por isso a questão de um direito plural, ou seja, dos humanos. Nesse sentido, a questão dos direitos das gentes, seria

Nesta perspectiva, Jaca entende que a implicação destas ideias se dá com o direito das gentes onde se fundamenta as relações entre as mais diferentes e diversas comunidades e indivíduos, e da mesma maneira que se faz com o direito natural tem de se construir uma doutrina que estabeleça o que seja o estatuto da lei e da justiça nas relações humanas. O dispositivo da guerra justa é analisado por Jaca no sentido de que esta só pode acontecer se houver a averiguação que entenda que esta seja autêntica e legítima (DECOTHÉ JÚNIOR, 2017, p. 33).

Com isso, a questão da guerra justa foi utilizada como um instrumento retórico para uma justificação dos negócios. O resultado seria a licitude da escravidão. Contudo, a legitimação foi corroborada pelas instituições reais e eclesiais da época. $\mathrm{O}$ argumento da guerra justa, era necessário para enfrentar os infiéis e com isso, julgá-los com a justiça, esse foi argumento de legitimação para escravizar ou outro. Entretanto, ocorreu que os primeiros infiéis foram os negociantes ou aqueles que financiavam as expedições, pois negaram a condição de humanidade do outro. O sentimento de empatia mais uma vez negado e os pertencentes aos demais reinos pelo continente africano foram retirados de suas terras ou vendidos pelos seus inimigos, como aqueles homens sacros sem direito e sem nome.

\section{A RETIRADA DA ESCRAVIDÃO DO MUNDO, É POSSÍVEL?}

Retirada é a ação que determinada pessoa, grupo social ou indivíduo com o poder representativo poderá realizar no âmbito de sua convivência. O questionamento dessa seção do texto é referente a dificuldade social em se discutir sobre o assunto escravidão. Por conseguinte, discutiremos sobre a forma de vida e a 'Forma-de-Vida', termos apresentados por Giorgio Agamben (2017). O último termo é razão do 'campo', nesse caso, da 'senzala'. Isso representa a questão da exceção como paradigma para o processo político colonial.

Nessa acepção, o escravo é comparado ao Homo Sacer de Giorgio Agamben, aquele denominado de um ser sem importância, denominado de 'sacro', a ironia 
desse termo. À vista disso, o conceito apresentado por Giorgio Agamben (2002), em razão do estado de exceção caracteriza o indivíduo desprezado do espaço público/comunidade. Exemplo disso, o escravo retirado do seu ambiente público de origem. A conquista do outro, tutelado por um direito estatal, representa a exceção. Por isso, a ação de escravizar o outro não é algo aleatório, era preciso uma legitimação para as 'cartas comerciais' terem algum valor agregado. O paradoxo era que o contrabando de 'escravos africanos' para as colônias, era considerado um crime contra o Rei e a submissão do outro, poderia ser considerado uma 'normalidade.

Por isso, o conceito inerente ao título dessa seção é o conceito de vida. Sendo assim, dois questionamentos são aporias para uma discussão sobre o tema. O primeiro, o que seria o homem? Perguntou o revolucionário francês da razão para delimitar direitos para o homem, especialmente a liberdade, esse em período posterior ao mercado colonial. Anteriormente, questionou-se o Capuchinho Francisco José de Jaca: o que seria o humano escravo? Poderia afirmar que o termo antecedente desses dois questionamentos seria o conceito de vida.

Consequentemente, a influência do pensamento de Giorgio Agamben (2017) para conceituar o termo vida é fruto da influência grega, ou seja, a condição da bios e zoé3. Com isso, mesmo com duas variantes conceituais para o termo vida, a característica conceitual de convergência é: a capacidade da ação de viver em comunidade, ou seja, a forma de vida. Quando o indivíduo é capturado e avalizado por determinado preço, sob ele a coerção de abandonar a forma de vida e passar a uma determinada vida nua, o sistema escravocrata incide como meio inicial a uma vida destituída do estatuto jurídico e social. À vista disso, Giorgio Agamben (2017) no ensaio Forma-de-Vida para o livro Meios sem fim (1996) e depois em Uso dos corpos (2014), dedica a terceira parte de seu livro à discussão do tema. Sobre vida nua, Costa afirma

\begin{abstract}
A vida da qual trata Agamben é a vida nua, vida que foi reduzida ao estatuto da indisposição da lei e se encontra numa zona indiscernível em que natureza e política se indeterminam para ser exercida a força ou a violência soberana. Desprovida do estatuto jurídico que lhe contextualiza no tecido político, a vida nua é abandonada pela proteção soberana em razão de sê-la um perigo à ordem social, e é vida excedida na natureza, ao passo em que não é apenas parte de uma espécie de animais ou plantas. (2019, p. 143)
\end{abstract}

Uma vida desprovida de essência política, social ou econômica, apresenta ter algum tipo de uso? Na primeira parte do livro Uso dos Corpos (2014), Agamben intitula como o "O

\footnotetext{
${ }^{3}$ Os gregos não tinham um termo único para exprimir o que entendemos pela palavra vida. Serviamse de dois termos semântica e morfologicamente distintos: zoé, que manifestava o simples fato de viver, comum a todos os viventes (animais, homens ou deuses), e bios, que significava a forma ou maneira de viver própria de um indivíduo ou de um grupo (AGAMBEN, 2017, p. 13).
} 
Homem Sem Obra" e começa com a explicação sobre o termo uso dos corpos, decerto sobre a influência aristotélica para a discussão sobre o uso. Com a questão da escravidão, o autor discute a relação do escravo como parte do corpo do seu senhor, pois como coisa/objeto estaria sob a tutela do seu senhor. Sendo assim, "a aproximação do escravo a um ketma implica, para Aristóteles, que ele seja parte (morion) do senhor - parte em sentido integral e constitutivo" (AGAMBEN, 2017, p.31). Isso corrobora a questão da passagem do indivíduo capturado (como vida nua), para o indivíduo escravo, que é considerado como uma forma-de-vida. Sendo assim, o escravo realiza por meio de sua potência do trabalho a vontade soberana do seu senhor, além de dispor da tutela jurídica. Nascimento (2018), indica-nos a capacidade da experiência da forma-de-vida como: "para que a forma-de-vida possa ser encontrada é preciso depor toda condição social e propriedade jurídica [...]” (p.26). Por isso, a questão do depor, ou seja, a retirada da condição de vida, por isso é a nova forma do uso deste corpo, seja social ou político ou ainda o corpo comunitário.

A questão do uso do corpo em comparação a questão da escravidão, foi dado ao homem a adjetivação de coisa móvel. Posto isto, o momento que o homem passa de gente à coisa é a transformação do indivíduo em utilidade de um trabalho coercivo e sem o exercício de seus direitos inerentes à condição de humanidade e de cidadão. Por isso, o homem torna-se coisa móvel e com um preço determinado, quando há o encontro deste com o seu local de desumanização, nesse caso a 'senzala' como 'campo', o local do desencontro da vida. Com isso, Giorgio Agamben, indica-nos

A assemelhação do escravo a um móvel e a um instrumento é aqui desenvolvida distinguindo, sobretudo, os instrumentos produtivos e os instrumentos de uso (que não produzem nada, a não ser seu uso). Assim, na expressão "uso do corpo", uso deve ser entendido em sentido não produtivo, mas prático: o uso do corpo do escravo é semelhante àquele do leito ou da roupa, não àquele da lançadeira ou da palheta (2017, p.30).

Nessa citação, Agamben indica o sentido do uso como praticidade, pois o humano transformado em escravo, tem a desumanização como processo utilitário para o desenvolvimento da máquina de exploração colonial. Com isso, o uso do humano escravo é prático, pois sua vida é elegível a condição de coisa, além de ser elegível ao descarte social de não ser uma prática remunerada. Sobre o sentido dessa citação dois argumentos são inerentes ao discurso de José Jaca, a questão do "uso" e da "prática", pois para o capuchinho esse foram mecanismos/instrumentos de redução do homem a condição do nada social, político e econômico. 
Por isso, retomemos a discussão sobre a possibilidade da retirada da escravidão do mundo, aparece-nos uma amplitude ou impossibilidade. Contudo, o sentido da retirada é no sentido da possibilidade da discussão e a disposição das sociedades que foram colônias no período colonial e, hoje, as que exercem esse processo contemporâneo (termo da uberização do trabalho $)^{4}$. Escravidão não é um tema fácil de discussão, pois existe um racismo de discurso, isto é, a negação de discutir condições para reparação dos discursos. O processo de aceitação de uma comunidade plural seria o processo político de compreender o outro. Retirada da escravidão é o retirar das barreiras para a discussão e o compreender todo o processo.

Sendo assim, os números mundiais da Organização Internacional do Trabalho são assustadores, mostram que o Estado democrático de direito é prático para determinadas comunidades, por isso, Cartas de liberdades, Estatutos ou Declarações, o intervalo de tempo da segunda escolástica ao contemporâneo, são quase 600 anos e o tema (escravidão), representa um assunto delicado ao debate na Academia, aos governos e ao comum. Assim, o capuchinho José Jaca, entendeu que a retirada da escravidão só seria possível, quando o homem entendesse a condição de empatia ao outro.

Nessa acepção, o escravo é comparado ao Homo Sacer de Giorgio Agamben, um ser sem importância, denominado de 'sacro', a ironia do termo. Pois, a retirada do ambiente público e do direito em conviver em sociedade. Retomando o conceito apresentado por Giorgio Agamben, em razão do estado de exceção que caracteriza o indivíduo. Exemplo disso, o escravo retirado do seu ambiente público. Seria a conquista do outro, tutelado por um direito estatal, representa a exceção. Por isso, a ação de escravizar o outro não é algo aleatório, era preciso uma legitimação para as 'cartas comerciais' terem algum valor agregado. O paradoxo era que o contrabando de 'escravos africanos' para as colônias, era considerado um crime contra o Rei e a submissão do outro, poderia ser considerado uma 'normalidade. Logo, a vida é banalizada pela separação que o colonizador propiciou ao outro, pois ocorreu a 'coisificação' da vida, assim

A vida do homo sacer existe numa zona de anomia em que é capturada pelo abandono. Ela vive relegada à condição de pura vida natural [zoe]; sobreviver entre o direito divino (que não a reconhece pura o suficiente para o sacrifício) e o direito humano (que a excluiu de qualquer direito). Quando é decretada a condição de sacer sobre alguém, o direito da polis fica ipso facto retirado da vida do cidadão. Ele deixa de ser cidadão para se converter em mero homo, um homo comunis. O homo comunis, contrastando com o cidadão protegido pelo direito sagrado, era um mero ser humano; ele

\footnotetext{
${ }^{4}$ Processo em que o indivíduo se torna "prático" para o trabalho de terceiros, assumem toda responsabilidade da cadeia do trabalho. 
existia fora do direito, sem direitos, reduzido, portanto, à condição de vida nua (RUIZ, 2013a, p.334).

Dessa forma, discutir sobre o abandono é negar a condição de vida ao outro em viver, por meio de sua liberdade. Sobre a retirada do tema, ocorre pela não vontade de discutirmos em razão dos acontecimentos pretéritos. Sendo assim, o dever de testemunho não é do agente que sofreu a barbárie em ser escravo do outro.

A possibilidade de a escravidão ser retirada do mundo é possível, no momento que o outro compreender e oferecer testemunho, em razão da liberdade para com o outro. O debate é sobre séculos de escravidão, exatamente o período colonial e de expansão dos reinos de Portugal e Espanha, local seriam as Antilhas ou que compreendem as colônias da América, isso o passado. O hoje, 70 anos após a publicação da Declaração Universal dos Direitos Humanos, em especial o artigo $4^{\circ}$, condena o trabalho escravo, "Ninguém será mantido em escravidão ou servidão; a escravidão e o tráfico de escravos serão proibidos em todas as suas formas". Atualmente, transformou a escravidão não pela cor ou pelo lugar e sim pela necessidade comercial, além de globalizar essa ideologia. A OIT, revela que são mais de 40 milhões ${ }^{5}$ de pessoas que vivem nas condições relatadas nas palavras da Declaração. Essa confirmação, indica-nos o testemunho passado é pela continuidade da violência do humano em negar o humano. Por isso

As pessoas que não pertenciam a uma casa eram pessoas sem direito, porque estavam fora da sacralidade instituinte das famílias. Sem a sacralidade do direito das casas, as pessoas ficavam abandonadas. Nessa condição vemos reproduzir-se a figura do homo sacer, porém com uma diferença importante: as pessoas que viviam sem direito, que eram muitas, viviam a condição da exceção de fato, embora não de direito. O homo sacer é um decreto de direito que retira o direito de cidadania de um cidadão e o condena a viver fora do direito (RUIZ, 2013b, p.72).

O sentimento universal de propiciar direitos não foram correspondidos. Ocorreu o inverso, ou seja, a manutenção da servidão, por meio da escravidão, são resquícios da sociedade que não debateu o real motivo da escravidão. Nesse sentido, "ao contrário, limita-a, pois, a exigência de grave necessidade é substituída pela exigência de uma extrema necessidade, entendida como alto risco de perder a vida natural" (D’OCA, 2017, p.298). Mesmo em períodos sobre resoluções de direitos e a preocupação mundial em combater a negação desses, a

\footnotetext{
${ }^{5}$ Dados da OIT e da Walk Free Foundation referente ao ano de 2016.
} 
amplitude do risco em perder o direito como acepção de vida é ampla. Os números ainda não são claros, mesmo com a indicação dos 40 milhões ou esses números são superiores.

Por isso, a escravidão representa a condição de violência, consequência do 'estado de exceção, tanto no passado com a negação da liberdade, quanto no presente período com os meios modernizados. Em razão disso, a 'senzala' passou por uma atualização, não mais os 'ferros ou grilhões', sim, as máquinas em ambientes fechados. Por conseguinte, o termo que poderíamos objetivar como uma 'senzala digital', ou seja, o meio informacional em atualizar os sistemas e maquinários fabris, geram a capacidade da escravização do homem pela máquina, em querer este conquistar a 'meta' para conseguir o alimento diário. Portanto, a questão de convergência do pensamento entre Francisco José de Jaca e Giorgio Agamben, está no elemento 'exceção'

São dois os pilares que orientam a reflexão de Agamben neste momento histórico, sempre duplamente implicados e referenciados: primeiro, o estado de exceção se tornou uma técnica de governo comum no nosso tempo político, pelo menos a partir do seu uso laboratorial nos eventos totalitários do início do século vinte; segundo, a exceção é o elemento multitemporal originário da constituição jurídica e política (NASCIMENTO, 2016, p.20).

Por conseguinte, o evento 'exceção' é a condição da supressão de direitos e princípios, por exemplo, a retirada da condição de vida. A citação anterior, representa a soberania da Instituição política, o Estado, exercendo o poder máximo. Enquanto, no período colonial a soberania era do senhor colonial com sua redução territorial, que seria um supra direito ao da Metrópole, premissa da configuração do 'estado de exceção', que é a superioridade da vontade subjetiva ou coletiva, pela normalidade do costume em comunidade. Assim, o direito originário dessas vontades extemporâneas, são consequências para a violência e a instrumentalização dessa. Portanto, Agamben, no texto forma de vida, indica-nos

A vida aparece, assim, originariamente no direito, somente como parte contrária de um poder que ameaça de morte do pater vale com maior razão para o poder do soberano (imperium), do qual o primeiro constitui a célula originária. Assim, na fundação hobessiana da soberania, a vida no estado de natureza só é definida pelo seu ser incondicionadamente exposta a uma ameaça de morte (o direito ilimitado de todos sobre o tudo), e a vida política, isto é, aquela que desenvolve sob a proteção do Leviatã, não é senão a mesma vida, exposta a uma ameaça que repousa, agora, apenas nas mãos do soberano (AGAMBEN, 2017, p.15). 
Agamben, na citação invoca a natalidade, que para o direito seria o elemento garantidor e não exceção. A busca de proteção é percepção do indivíduo, consequência de ameaça, por isso, o soberano assume o poder de proteção aos súditos ou ao povo. O escravo como propriedade foi tutelado pelo senhor colonial, o argumento de proteção é disponível para ele. Contudo, o direito de fala é suprimido em comparação ao indivíduo livre, o senhor era detentor do poder de vida e de morte, exemplo disso, seria o 'tronco', a ameaça constante para o escravo.

Por isso, a constante da ameaça é o período do ‘terror' em não saber o acontecimento posterior ou a usurpação de direitos ou no que Mbembe, denominou de "Necropolítica" em uma tradução literal, a morte da política e com ela os direitos. Para o autor é importante destacar a questão da liberdade do sujeito e o respeito pelo outro. Ou seja, o momento de convergência ao pensamento de Jaca em defender a humanidade do sujeito em ser livre para desempenhar atividades, entretanto, seu limite o espaço distinto. Consequentemente, transgressões de direitos e a justificação pela escravidão são um desencontro do outro e consigo mesmo. Ainda sobre o pensamento de Mbembe, há destaque para o sentido do espaço público, nesse sentido o homem na condição de escravo, foi usurpado do seu espaço de convivência. Hoje, mais uma vez é retirado para longe de si e do outro. Nesse sentido

Em outras palavras, é com base em uma distinção entre razão e desrazão (paixão, fantasia) que a crítica tardo-moderna tem sido capaz de articular uma certa ideia de política, comunidade, sujeito - ou, mais fundamentalmente, do que abarca uma vida plena, de como alcançá-la e, nesse processo, tornar-se agente plenamente moral. Nesse paradigma, a razão é a verdade do sujeito, e a política é o exercício da razão na esfera pública. O exercício da razão equivale ao exercício da liberdade, um elementochave para a autonomia individual (MBEMBE, 2016, p.124).

A respeito de indagar a autonomia, ela representa a questão dos "direitos das gentes" e a liberdade seria a confirmação de viver em comunidade. Entretanto, hoje o comerciante não mais aguarda "os navios negreiros", pelo contrário esperam o caminhar dos próprios homens, mulheres e crianças para serem "servos" ou "colaboradores" das empresas multinacionais, por exemplo, a indústria da moda e do minério, o caminhar é um paradoxo. Pois, a liberdade que um direito seu em viver em comunidade é o mesmo que o (leva) pela necessidade a se submeter a nova escravidão. Com isso, a retirada da discussão do tema escravidão, infelizmente é uma impossibilidade para o direito e para as instituições. A sociedade não debate, não há uma reparação. Existe uma profanação de direitos e liberdades, sendo assim

A intimidade com uma zona de não-conhecimento é uma prática mística cotidiana, na qual, Eu, numa forma de esoterismo especial e alegre, assiste sorrindo ao próprio desmantelamento e, quer se 
trate da digestão do alimento, quer da iluminação da mente, é testemunha, incrédulo, do incessante insucesso próprio. (AGAMBEN, 2007, p.17).

A sociedade, nesse caso, não compreendeu o sentimento de liberdade. O espetáculo da vida é a transformação em um objeto prático. O princípio da fraternidade foi esquecido. A intimidade em não conhecer o outro e não o respeitar é a consequência em confirmar, a não retirada da escravidão pelo mundo. Todo o processo ocorrido com os milhares de africanos retirados dos seus espaços, todo esquecido. Esses testemunhos foram sufocados ou desacreditados, quem ouviu falar em Francisco José de Jaca, um capuchinho? Seu testemunho, conflagrou o alerta e rememorou o sentimento de liberdade em uma sociedade que demorou séculos em tentar entender o outro. O Homo Sacer torna-se testemunha do hoje da escravidão digital; de discurso e colonial, pois não ocorreu a superação do tema da escravidão, pois o argumento do testemunho é convergência de José de Jaca com o pensamento de Agamben, com isso

A testemunha comumente testemunha a favor da verdade e da justiça, e delas a sua palavra extrai consistência e plenitude. Nesse caso, porém, o testemunho vale essencialmente por aquilo que nele falta; contém, no seu centro, algo intestemunhável, que destitui a autoridade dos sobreviventes. As "verdadeiras" testemunhas, as "testemunhas integrais" são as que não testemunharam, nem teria podido fazê-lo (2008, p.43).

Portanto, a escravidão é testemunha da possibilidade da transformação do outro em coisa, negando o humano. Pois o discurso de José Jaca é testemunha de representar o humano, pois sua ação de testemunhar perante os tribunais eclesiásticos e políticos, representou a retirada da negação humana da "Senzala" para a sociedade que aceitou o índio como humano, que disse não ao tipo de escravidão. Pois no pensar do capuchinho o homem deveria ser retirado dessa condição, pois ele expressava o reflexo da semelhança com o criador, pois a vida era um dom ou nas palavras de Agamben, a vida é sacra. Por isso, o capuchinho se tornou testemunha da condição de vida.

\section{CONSIDERAÇÕES FINAIS}

"Stamos em pleno mar", assim declamou Castro Alves (2013), pois representa a travessia e o despojo da condição de uma vida política para o negar da vida. A missão de Francisco José de Jaca era o resgate político e religioso da vida 
do humano, esse desprezado do sentido de participante de uma comunidade social. Os argumentos de legitimação desse despojo social, foram baseados em conceitos teologais. Pois Tomás de Aquino como um doutor da Igreja discutiu sobre a alma e a condição de servo, devido ao elemento do pecado como motivo de alguns servirem e outros não, ou seja, de serem escravos.

Contudo, o capuchinho utilizou sua formação de vida para salvar o outro, a premissa das palavras cristãs. Sendo assim, ele foi a resistência da sociedade da época e a incompreensão, a consequência foi a perseguição. De tribunal em tribunal e o seu respeito ao Rei Carlos II, realizou o bom combate pelas palavras sacras, os exemplos dos relatos. Sua premissa foi relembrar a nossa semelhança com a do criador. Os contra-argumentos foram interpretações retóricas, o sentimento era manter a instituição e o comércio, assim o fizeram. O sentimento do ontem e do hoje em não retirar a escravidão do mundo, é que mesmo com o exemplo de Francisco José de Jaca em defender o outro, ainda ocorre a não compreensão da liberdade. A fraternidade como princípio é esquecida, quando a ameaça surge para o outro. Entretanto, os argumentos utilizados pelo capuchinho não permaneceram nas palavras. Enfrentou os tribunais eclesiásticos e políticos, com isso, pode ser considerado precursor do combate institucionalizado à escravidão.

A escravidão é o paradigma para o conceito de vida, pois na interpretação de pensamento em Giorgio Agamben, vida não é só a condição biológica e sim o exercício político em comunidade. Sendo assim, a questão da retirada da vida política transforma o indivíduo em uma "vida nua", essa desprovida da assistência jurídica e política. Por isso, o sistema escravocrata colonial é comparado a uma máquina de desumanização, ou seja, negar a humanidade ao indivíduo que não compartilha as mesmas características sociais e políticas.

Com isso, o instrumento do "uso dos corpos" foi o "campo" como elemento da exceção, ou seja, o local para negar o outro. O primeiro "campo" para o período colonial seria o "navio negreiro", esse era quem realizava a travessia do humano para a condição da desumanidade, esses mesmo acorrentados, tentavam preservar sua língua e diálogo com os demais, ou seja, uma proximidade pela condição do diálogo. Outro exemplo, foi o 'navio negreiro' e a 'senzala', esses locais do encontro do humano com sua condição de não-humano, que representa uma Forma-de-Vida. Sendo esse processo de negar a vida, pois a forma de vida é rompida com o processo de escravizar o outro. Por conseguinte, a escravidão se tornou para o homem com uma forma-de-vida, ou seja, a retirada do indivíduo da sua comunidade de origem.

A contiguidade de pensamento entre Francisco José de Jaca e Giorgio Agamben, está na apresentação da instrumentalização da violência em razão do 
homem para o homem. O Homo Sacer, representa a violência e uma vida nua, tanto política, quanto jurídica. Portanto, a escravidão representa a negação da vida política, uma das formas do estado de exceção. A sacralidade da vida não está contida na natalidade e sim no compreender o outro e a convivência da pluralidade no mesmo ambiente público, pois os dois autores apresentam um sentimento de substituir o termo 'retirada social/política de um indivíduo' para o resgate da condição de bios, ou seja, o exercício da vida em liberdade em comunidade. Entretanto, ainda estamos em alto mar, na impossibilidade de retirar o outro da escravidão e não discutir sobre o tema. À vista disso, evitamos que o 'uso dos corpos' seja, apenas uma 'prática' de exploração social ou econômica e que a sociedade seja questionada para evitar a fatalidade do esquecimento pelo outro, pois temos que evitar o alto mar do esquecimento social pelo outro e do político tema da escravidão. 


\section{REFERÊNCIAS BIBLIOGRÁFICAS}

AGAMBEN, Giorgio. Meios Sem Fim: Nota Sobre a Política. Tradução de Davi Carneiro. 1. ed. 3. reimp. Belo Horizonte: Autêntica Editora, 2017.

O Que Resta de Auschwitz. Tradução de Selvino J. Assmann. São Paulo: Editora Boitempo, 2008.

Profanações. Tradução de Selvino J. Assmann. São Paulo: Editora Boitempo, 2007.

. Homo Sacer: O Poder Soberano e a Vida Nua I. Tradução de Henrique Burigo.

Belo Horizonte: Editora UFMG, 2002.

ALVES, Castro. Navio Negreiro e Outros Poemas. São Paulo: Melhoramentos, 2013.

ARISTÓTELES. Metafísica. Tradução de Giovanni Reale. São Paulo: Edições Loyola, 2002.

AQUINO, Tomás. Suma Teológica. 2. ed. São Paulo: Edições Loyola, 2001.

BAPTISTA, Mauro Rocha. Notas Sobre o Conceito de Vida em Giorgio Agamben. Revista Profanações, Cidade, a. 1, n. 1, p. 53-74, jan./jun. 2014.

COSTA FILHO, Willian. Por Que Viver Entre Hifens? A Relação Entre Regra e Vida na Filosofia de Giorgio Agamben. Revista Controvérsia, São Leopoldo, v.15, n. 3, p.139-158, set./dez., 2019.

DECOTHÉ JÚNIOR, Joel. Aspectos da Crítica de Francisco José de Jaca à Ideologia da Escravidão na Escolástica Colonial. Problemata: R. Intern. Fil. João Pessoa, v. 8. n. 3, p. 20-38, 2017.

D’OCA, Fernando Rodrigues Montes. O Discurso Antiescravista de Epifanio de Moirans Sobre os Títulos de Escravidão. Síntese. Belo Horizonte, v.44, n.139, p.279-303, mai./ago., 2017

JACA, Francisco José de. Resolución Sobre la Libertad de los Negros y sus Originarios, en Estado de Paganos y Después ya Cristianos. Ed. Miguel Anxo Pena González. Madrid: Consejo de Investigaciones Científicas, 2002.

MBEMBE, Achille. Necropolítica. Revista Arte e Ensaios. Rio de Janeiro, a.22, n.32, p. 122-151, 2016.

NASCIMENTO, Daniel Arruda. Em Torno de Giorgio Agamben: Sobre a Política Que Não Se Vê. 1. ed. São Paulo: Editora LiberArs, 2018.

. A Exceção Colonial Brasileira: O Campo Biopolítico e a Senzala.

Cadernos de Ética e Filosofia Política. São Paulo, n.28, p. 19-35, 2016. 
RUIZ, Castor M. M. Bartolomé. A Condição do Homo Sacer. O Direito e a Arqueologia do Sagrado, um Diálogo com Giorgio Agamben. Revista Portuguesa de Filosofia, Lisboa, t. 69, fasc. 2, pp. 331-348, 2013 a.

. Os Paradoxos da Sacralidade da Vida Humana: Questões Ético-Políticas do Pensamento de W. Benjamin e G. Agamben. Revista de Filosofia Aurora, Curitiba, v. 25, n.37, p.57-77, jul./dez., 2013 b.

SANTOS, Vanilda Honória. O Homo Sacer e a Exclusão do Outro: Algumas Considerações. Revista Profanações, cidade, a. 1, n. 2, p. 70-81, jul./dez. 2014.

SILVA, Ricardo da. A Teoria do Estado de Exceção em Giorgio Agamben e a Exceção Brasileira. Revista Profanações, cidade, a.3, n.1, p.161-177, jan./jul., 2016.

ONU. Mais de 40 milhões de pessoas ainda são vítimas de trabalho escravo no mundo. Disponível em: <https://nacoesunidas.org/mais-de-40-milhoes-de-pessoas-ainda-sao-vitimasde-trabalho-escravo-no-mundo/>. Acesso em: 27 ago. 2019. 